\title{
Membrane Cofactor Protein
}

National Cancer Institute

\section{Source}

National Cancer Institute. Membrane Cofactor Protein. NCI Thesaurus. Code C126979.

Membrane cofactor protein (392 aa, $\sim 44 \mathrm{kDa}$ ) is encoded by the human CD46 gene. This protein is involved in the classical complementation pathway, pathogen binding, fertilization and T-cell differentiation. 